\title{
Prevalence of hereditary risk factors for thrombophilia in Belém, Brazilian Amazon
}

\author{
France Keiko Nascimento Yoshioka ${ }^{1}$, Amélia Góes Araújo ${ }^{2}$, Marli Haydee Tavella ${ }^{2}$, \\ Igor Guerreiro Hamoy ${ }^{1}$ and João Farias Guerreiro ${ }^{1}$ \\ ${ }^{1}$ Universidade Federal do Pará, Centro de Ciências Biológicas, Departamento de Patologia, \\ Laboratório de Genética Humana e Médica, Belém, PA, Brazil. \\ ${ }^{2}$ Universidade de São Paulo, Faculdade de Medicina de Ribeirão Ribeirão Preto, \\ Departamento de Medicina Clínica, Laboratório de Hematologia,Ribeirão Preto, SP, Brazil.
}

\begin{abstract}
Different risk factors for venous thromboembolism (VTE) have been identified, including hereditary abnormalities in the mechanisms of coagulation and fibrinolysis. We investigated five genetic polymorphisms ( $F V L$ G1691A, FII G20210A, MTHFR C677T, TAFI A152G and TAFI T1053C) associated with VTE in individuals from the city of Belém in the Brazilian Amazon who had no history of VTE. No significant difference was found between the observed and expected genotype frequencies for the loci analyzed. We found high frequencies of MTHFR C677T (33.9\%) and TAFI T1053C (74\%) and low frequencies of FVL (1.6\%), FII G20210A (0.8\%) and TAFI A152G (0.8\%). The FVL G1691A, FII G20210A and MTHFR C677T frequencies were similar to those for European populations and populations of European descent living in the city of Ribeirão Preto in the Brazilian state of São Paulo. The frequency of the two TAFI mutations in the Belém individuals was not significantly different from that described for individuals from Ribeirão Preto. We suggest that the risks for VTE in the population of Belém are of the same magnitude as that observed in European populations and in populations with an expressive European contribution.
\end{abstract}

Key words: factor V Leiden, prothrombin, MTHFR, TAFI, thrombophilia.

Received: January 21, 2005; Accepted: July 5, 2005.

Thrombophilia can be defined as an increased tendency towards thrombosis (venous and arterial) through enhanced coagulation. Over the past few decades genetic defects in proteins regulating blood coagulation have been established as risk factors predisposing to venous thromboembolism (VTE). Such genetic defects are relatively frequent, the most important of which are antithrombin, protein $\mathrm{C}$ or protein $\mathrm{S}$ deficiency or resistance to activated protein $\mathrm{C}$ due to the factor V Leiden ( $F V L$ G1691A) or factor II prothrombin (FII G20210A) gene mutations (Lane and Grant, 2000). Other potential genetic polymorphisms have also been studied, including the thermolabile variant of the methylenetetrahydrofolate reductase (MTHFR) gene (Arruda et al., 1997) and polymorphisms in the 5'-untranslated region (5'-UTR) of the thrombin-activatable fibrinolysis inhibitor (TAFI) gene (TAFI A152G and TAFI $T 1053 C$ ), which plays an important role in hemostasis by

Send correspondence to João Farias Guerreiro. Universidade Federal do Pará, Centro de Ciências Biológicas, Departamento de Patologia, Laboratório de Genética Humana e Médica, 66075-970 Belém, PA, Brazil. E-mail: joaofg@ufpa.br. functioning as a potent fibrinolysis inhibitor (Franco et al., 2001

The available studies show a high prevalence of $F V L$ G1691A, FII G20210A and MTHFR C677T polymorphisms in Europeans (Adamczuk et al., 2000; Angelopoulou et al., 2000; Araújo et al., 2000) but the frequency of the TAFI A152G and TAFI T1053C polymorphisms are less well-known.

We present the results of a study designed to evaluate the prevalence of five polymorphisms ( $F V L$ G1691A, FII G20210A, MTHFR C677T, TAFI A152G and TAFI T1053C) in a population sample from the city of Belém, the capital of the state of Pará in the Brazilian Amazon.

The general Belém population has resulted from an intense process of admixture between Caucasians (principally of Portuguese descent), Blacks (descendants of African slaves) and Amerindians. This study was approved by the ethics committee of our institution.

Blood was collected after informed consent from 73 females and 54 males, $(n=127$, median age 23 years, range 18-44) with no history of VTE and the DNA extracted by the standard phenol-chloroform method. Genotyping for 
Table 1 - Allele and genotype frequencies of the factor V Leiden (FVL G1691A), factor II prothrombin (FII G20210A), methylenetetrahydrofolate reductase (MTHFR C677T) and thrombin-activatable fibrinolysis inhibitor (TAFI A152G and TAFI T1053C) polymorphisms in a population sample $(\mathrm{N}=127)$ from the Brazilian city of Belém.

\begin{tabular}{|c|c|c|c|c|c|c|c|c|}
\hline \multirow[b]{2}{*}{ Locus } & \multicolumn{6}{|c|}{ Genotype frequency } & \multicolumn{2}{|c|}{ Allele frequency } \\
\hline & Genotype & Frequency $(\%)$ & Genotype & Frequency $(\%)$ & Genotype & Frequency (\%) & Allele & Frequency $(\%)$ \\
\hline FVL G1691A & GG & $123(97)$ & GA & $4(3)$ & $\mathrm{AA}$ & 0 & $\mathrm{~A}$ & 1.6 \\
\hline FII G20210A & GG & $125(98)$ & GA & $2(2)$ & AA & 0 & A & 0.8 \\
\hline MTHFR C677T & $\mathrm{CC}$ & $56(44)$ & $\mathrm{CT}$ & $56(44)$ & $\mathrm{TT}$ & $15(12)$ & $\mathrm{T}$ & 33.9 \\
\hline TAFI A152G & AA & $125(98)$ & $\mathrm{AG}$ & $2(2)$ & GG & 0 & G & 0.8 \\
\hline TAFI T1053C & TT & $8(6.3)$ & $\mathrm{TC}$ & $50(39.4)$ & $\mathrm{CC}$ & $69(54.3)$ & $\mathrm{C}$ & 74 \\
\hline
\end{tabular}

the five polymorphisms were performed by PCR amplification followed by MnlI, HindIII, HinfI, SspI and MspI restriction digestion, respectively, using primers described previously (Bertina et al., 1994; Poort et al., 1996; Frosst et al., 1995; Franco et al., 2001).

The genotype and allele frequency distributions recorded for the five loci are presented in Table 1 . We found high frequencies of MTHFR C677T (33.9\%) and TAFI $T 1053 C(74.0 \%)$ but the other variants were less frequent, i.e. FVL G1691A (1.6\%), FII G20210A (0.8\%) and TAFI $A 152 G(0.8 \%)$. For all loci the genotype distributions were consistent with the expected Hardy-Weinberg values.

The factor $\mathrm{V}$ Leiden allele is present in about $4-5 \%$ of the normal white population, but is rare or absent among Asia, Africa, America and Australia indigenous populations (Zivelin et al., 1997). In our study the observed $F V L$ $G 1691 A$ frequency (1.6\%) did not differ significantly from the frequencies observed in most of Caucasian populations (Adamczuk et al., 2000) or from that reported by Franco et al. (1999) in Brazilians of European origin (1.3\%) and Brazilian Amerindians (0.3\%), but was significantly lower than the $6.9 \%$ found in Greeks (Angelopoulou et al., 2000).

The FII G20210A frequency is $1-8 \%$ in the general European population (Zivelin et al., 1998; Angelopoulou et al., 2000) but this gene is rare or absent in black Africans, Amerindians and Asians (Cumming et al., 1997; Rosendaal et al. 1998; Angchaisuksiri et al., 2000). In our study the observed FII G20210A frequency (0.8\%) was similar to that reported for most Caucasian populations, including Brazilians of European origin in a population sampled by Franco et al. (1998) in the Brazilian state of São Paulo where the frequency of this gene was also $0.8 \%$.

The frequency (34\%) of the MTHFR C677T gene in our sample was high and similar to that found in Europeans, Asians and Brazilian Amerindians (Franco et al. 1998; Botto and Yang et al., 2000), this frequency being significantly higher than those described in African populations and populations of North American and Brazilian blacks (Franco et al. 1998; Angelopoulou et al., 2000; Araújo et al., 2000; Wilcken et al., 2003).

Little is known globally about the frequency of polymorphisms in the 5'-UTR region of the TAFI gene, the only available data having been published by Franco et al. (2001) who reported a frequency of $2 \%$ for TAFI A152G and $75.6 \%$ for TAFI T1053C in a population sample from city of Ribeirão Preto in the Brazilian state of São Paulo. Our results for the TAFI polymorphisms (TAFI A152G= $0.8 \%$ and $T A F I-1053 C=74.0 \%$ ) did not differ significantly from those reported by Franco et al. (2001).

Our results show that in the population studied by us the frequency of polymorphisms related to the risk of VTE were in accordance not only with the expected values based on the available date on the distribution of these polymorphisms in human populations but also with the estimates by Santos and Guerreiro (1995) of the relative contributions of European (47\%), African (12\%) and Amerindian (41\%) genes to the population of Belém.

\section{References}

Adamczuk Y, Varela ML, Forastiero R, Martinuzzo M, Cerrato G, Pombo G and Carreras LO (2000) Factor V Leiden and prothrombin G20210A variant are risk factors for venous thromboembolism in the Argentinean population. Thromb Haemost 83:509-510.

Angchaisuksiri P, Pingsuthiwong S, Aryuchai K, Busabaratana M, Sura T, Atichartakarn V and Sritara P (2000) Prevalence of the G1691A mutation in the factor $\mathrm{V}$ gene (factor $\mathrm{V}$ Leiden) and the G20210A prothrombin gene mutation in the Thai population. Am J Hematol 65:119-122.

Angelopoulou K, Nicolaides A, Constantino U and Deltas C (2000) Prevalence of genetic mutations that predispose to thrombophilia in a Greek Cypriot population. Clin Appl Thromb Hemost 6:104-107.

Araújo F, Lopes M, Gonçalves L, Maciel MJ and Cunha-Ribeiro LM (2000) Hyperhomocysteinemia, MTHFR C677T genotype and low folate levels: A risk combination for acute coronary disease in a Portuguese population. Thromb Haemost 83:517-518.

Arruda VR, Annichino-Bizzacchi JM, Goncalves MS and Costa FF (1997) Prevalence of the prothrombin gene variant (nt20210A) in venous thrombosis and arterial disease. Thromb Haemost 78:1430-1433.

Bertina RM, Koeleman BPC, Koster T, Rosendaal FR, Dirven RJ, de Ronde H, van der Velden PA and Reitsma PH (1994) Mutation in blood coagulation factor $\mathrm{V}$ associated with resistance to activated protein C. Nature 369:64-67. 
Botto LD and Yang Q (2000) 5,10-methylenetetrahydrofolate reductase gene variants and congenital anomalies: A HuGE review. Am J Epidemiol 151:862-877.

Cumming AM, Keeney S, Salden A, Bhavnani M, Shwe KH and Hay RM (1997). The prothrombin gene 20210G/A variant: Prevalence in a UK anticoagulant clinic population. Br J Haematol 98:353-355.

Franco RF, Elion J, Santos SEB, Araújo AG, Tavella MH and Zago MA (1999) Heterogeneous ethnic distribution of factor V Leiden mutation. Genet Mol Biol 22:142-145.

Franco RF, Fagundes MG, Meijers JCM, Reitsma PH, Lourenço D, Morelli V, Maffei FH, Ferrari IC, Piccinato CE, Silva-Jr WA and Zago MA (2001) Identification of polymorphisms in the 5'-untranslated region of the TAFI levels and risk of venous thrombosis. Haematologica 86:510-517.

Franco RF, Santos SEB, Elion J, Tavella MH and Zago MA (1998) Prevalence of the 20210G/A polymorphism in the 3'-untranslated region of the prothrombin gene in different human populations. Acta Haematol 100:9-12.

Frosst P, Blom HJ, Milos R, Goyette P, Sheppard CA, Matthews RG, Boers GJ, Den Heijer M, Kluijtmans LA, Van Den Heuvel LP and Rozen P (1995) A candidate genetic risk factor for vascular disease: A common mutation in methylenetetrahydrofolate reductase. Nat Genet 10:111-113.

Lane DA and Grant PJ (2000) Role of hemostatic gene polymorphisms in venous and arterial thrombotic disease. Blood 95:1517-1532.

Poort SR, Rosendaal FR, Reitsma PH and Bertina RM (1996) A common genetic variation in the 3'-untranslated region of the prothrombin gene is associated with elevated plasma prothrombin levels and an increase in venous thrombosis. Blood 88:3698-703.

Rosendaal FR, Doggen CJ, Zivelin A, Arruda VR, Aiach M, Siscovick DS, Hillarp A, Watzke HH, Bernardi F, Cumming AM, Preston FE and Reitsma PH (1998) Geographic distribution of the $20210 \mathrm{G}$ to A prothrombin variant. Thromb Haemost 79:706-708.

Santos SEB and Guerreiro JF (1995) The indigenous contribution to the formation of the population of Braziliam Amazon region. Brazil J Genetics 18:311-315.

Wilcken B, Bamforth F, Li Z, Zhu H, Ritvanen A, Renlund M, Stoll C, Alembik Y, Dott B, Czeizel AE, Gelman-Kohan Z, Scarano G, Bianca S, Ettore G, Tenconi R, Bellato S, Scala I, Mutchinick OM, Lopez MA, de Walle H, Hofstra R, Joutchenko L, Kavteladze L, Bermejo E, Martinez-Frias ML, Gallagher M, Erickson JD, Vollset SE, Mastroiacovo P, Andria G, Botto LD and Redlund N (2003) Geographical and ethnic variation of the $677 \mathrm{C}$-T allele of 5,10 ethylenetetrahydrofolate reductase (MTHFR): Findings from over 7000 newborns from 16 areas worldwide. Med Genet 40:619-625.

Zivelin A, Griffin JH, Xu X, Pabinger I, Samama M, Conard J, Brenner B, Eldor A and Seligsohn U (1997) A single genetic origin for a common Caucasian risk factor for venous thrombosis. Blood 89:397-402.

Zivelin A, Rosenberg N, Faier S, Kornbrot N, Peretz H, Mannhalter C, Horellou MH and Seligsohn U (1998) A single genetic origin for the common prothrombotic G20210A polymorphism in the prothrombin gene. Blood 92:1119-1124.

Associate Editor: Francisco Mauro Salzano 